\title{
THERMAL CONDUCTIVITY OF THE HELIUM-ARGON SYSTEM
} by

A. Purohit and J. R. Moszynski

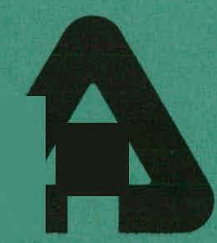

ARGONNE NATIONAL LABORATORY, ARGONNE, ILLINOIS

Prepared for the U. S. DEPARTMENT OF ENERGY under Contract W-31-109-Eng-38 


\section{DISCLAIMER}

This report was prepared as an account of work sponsored by an agency of the United States Government. Neither the United States Government nor any agency Thereof, nor any of their employees, makes any warranty, express or implied, or assumes any legal liability or responsibility for the accuracy, completeness, or usefulness of any information, apparatus, product, or process disclosed, or represents that its use would not infringe privately owned rights. Reference herein to any specific commercial product, process, or service by trade name, trademark, manufacturer, or otherwise does not necessarily constitute or imply its endorsement, recommendation, or favoring by the United States Government or any agency thereof. The views and opinions of authors expressed herein do not necessarily state or reflect those of the United States Government or any agency thereof. 


\section{DISCLAIMER}

Portions of this document may be illegible in electronic image products. Images are produced from the best available original document. 
The facilities of Argonne National Laboratory are owned by the United States Government. Under the terms of a contract (W-31-109-Eng-38) between the U. S. Department of Energy, Argonne Universities Association and The University of Chicago, the University employs the staff and operates the Laboratory in accordance with policies and programs formulated, approved and reviewed by the Association.

\section{MEMBERS OF ARGONNE UNIVERSITIES ASSOCIATION}

The University of Arizona

Carnegie-Mellon University

Case Western Reserve University

The University of Chicago

University of Cincinnati

Illinois Institute of Technology

University of 11 linois

Indiana University

Iowa State University

The University of Iowa
Kansas State University The University of Kansas Loyola University Marquette University Michigan State University The University of Michigan University of Minnesota University of Missouri Northwestern University University of Notre Dame
The Ohio State University Ohio University

The Pennsylvania State University Purdue University

Saint Louis University

Southern Illinois University The University of Texas at Austin Washington University Wayne State University The University of Wisconsin

\section{NOTICE}

This report was prepared as an account of work sponsored by the United States Government. Neither the United States nor the United States Department of Energy, nor any of their employees, nor any of their contractors, subcontractors, or their employees, makes any warranty, express or implied, or assumes any legal liability or responsibility for the accuracy, completeness or usefulness of any information, apparatus, product or process disclosed, or represents that its use would not infringe privately-owned rights. Mention of commercial products, their manufacturers, or their suppliers in this publication does not imply or connote approval or disapproval of the product by Argonne National Laboratory or the U. S. Department of Energy.

Printed in the United States of America Available from

National Technical Information Service

U. S. Department of Commerce 5285 Port Royal Road

Springfield, Virginia 22161

Price: Printed Copy $\$ 4.00$; Microfiche $\$ 3.00$ 
Distribution Category:

Gas Cooled Reactor Technology (UC-77)

ANL $-79-3$

ARGONNE NATIONAL LABORATORY

9700 South Cass Avenue

Argonne, Illinois 60439

THERMAL CONDUCTIVITY OF THE

HELIUM-ARGON SYSTEM

by

A. Purohit and J. R. Moszynski*

Materials Science Division

February 1979

- NOTICE

This report was prepared as an account of work

sponsored by the United States Government. Neither the

United States nor the United States Department of

Enerev. nor any of their employeos, nor any of their

contractors, subcontraciors, or their employees, makes

any wartanty, express or implied, or assumes any legal

liability or responsibility for the accuracy, completeness

or usefulness of any information, apparatus, product or

process disclosed, or represents that its use would not

infringe privately owned rights.

*Department of Mechanical Engineering, University of Delaware 
THIS PAGE

\section{WAS INTENTIONALLY \\ LEFT BLANK}


TABLE OF CONTENTS

\section{Page}

ABSTRACT . . . . . . . . . . . . . . . . . . . . . . . 1

I. INTRODUCTION . . . . . . . . . . . . . . . . . . . . 1

II. SOURCES OF DATA . . . . . . . . . . . . . . . . . . . . 4

III. PREDICTION METHODS . . . . . . . . . . . . . . . . . . . 5

REFERENCES . . . . . . . . . . . . . . . . . . . . . 14 


\title{
THERMAL CONDUCTIVITY OF THE HELIUM-ARGON SYSTEM
}

by

A. Purohit and J. R. Moszynski

\begin{abstract}
A semiempirical relation for the thermal conductivity of helium-argon gas mixtures is suggested. The analyses used in support of the proposed conductivity relations are based on low-temperature $\left(\mathrm{T}<800^{\circ} \mathrm{C}\right)$ thermal conductivity data for helium, argon and helium-argon mixtures. The report is a compilation of available data and theories, and does not contain any new experimental results. With the approach presented here, one should be able to predict thermal conductivities of helium-argon mixtures to within $5 \%$ of their true values for temperatures up to $1200 \mathrm{~K}$. The recommended equations are "best estimates" and should be treated as such. A definite need exists for experimental data to verify or modify the recommendation.

\section{INTRODUCTION}

The need for thermal-conductivity data on mixed gases has increased substantially in recent years. This is particularly true for several irradiation experiments in EBR-II and FTR, where material-performance data at temperatures significantly higher than the liquid-sodium coolant temperature can be obtained by what is commonly known as 'gas gapping' the spectmeis. This involves the placement of a known thermal-conductivity barrier between the specimen and the liquid-sodium coolant. The gap size can be chosen to obtain a prescribed temperature gradient along the axial length of a subassembly in the reactor. Helium-argon gas mixtures are frequently used because any desired
\end{abstract}


value of thermal conductivity between the high value of helium and the low value of argon can be achieved by adjusting the ratio of the two gases. The ability to vary the thermal conductivity gives the experimenter a wide latitude in sizing the physical extent of the gap. However, existing thermal-conductivity data on helium-argon gas mixtures are not only limited to temperatures of $800 \mathrm{~K}$, but are also contradictory for certain values of concentration ratio and temperature. In the course of designing an in-reactor experiment for the Gas-Cooled Fast Reactor cladding-development program, the need arose for (a) a "best estimate" of existing low-temperature data and (b) some extrapolation method for higher temperatures (at least until high-temperature data are available). Both of these objectives were achicved by the present authors and the details, including thermal-conductivity estimates, were made available to the EBR-II staff at ANL. They felt that such information would be of wider interest and should be made available in the form of a separate report. The primary intent of the present report is to give reactor experiments the current "best estimate" of thermal-conductivity values for the helium-argon system. Some theoretical background is also included for those who wish to consider. the complexity of the theoretical modeling.

The transport properties of dilute monatomic gases can, in principle, be calculated on the basis of now standard theory. ${ }^{1-3}$ (By "dilute" we mean gases in which binary molecular collisions play a dominant role and multiple collisions contribute only negligible or very minor corrections.) The reservation "in princtple" is necessary because the knowledge of intermolecular interaction potentials is inadequate to permit a direct calculation of all properties of interest for even the most simple gases. Even semiempirical schemes in which the intermolecular potential is deduced from one or more sets of data and then used to predict other data are not wholly successful. 
A recent1y proposed ${ }^{4-6}$ variant of the semiempirical approach, based on the theory of corresponding states, uses experimental data to determine a minimal set of scaling parameters describing the potential for a particular binary interaction and then makes use of universal functionals for the intermolecular potentials. This method, described in Section IIIB below, has been remarkably successful in correlating a wide variety of experimental data on viscosity, diffusion and second virial coefficients for monatomic and polyatomic gases and their mixtures. However, the method is much less successful with thermal-conductivity data, even for pure monatomic gases. This has led the architect of the method, J. Kestin, to observe ${ }^{5,6}$ that the available experimental thermal-conductivity data appear thermodynamically inconsistent with other experimental data of high precision, and to suggest that theoretically predicted thermal conductivities may be more reliable than the experimentally measured values, at least within clearly defined limits of the theory. The opposite view would hold that carefully and critically analyzed experimental data provide the only reliable test of any theory and that even with the aid of empirical equations, limited extrapolations of well-correlated, precise data offer the best chance of accurate predictions.

The determination of the thermal conductivity of helium-argon systems at 1000-1200K seems to require only a minor extrapolation of reported data. A careful examination of the data reveals certain possible shortcomings. Hence, complete reliance on empirical extrapolation is unsatisfactory. Happily, however, the proposed empirical extrapolation agrees quite well with the predictive method of Kestin and his coworkers and an averaging scheme is proposed which should yield results that are sufficiently accurate (i.e., within $\pm 5 \%$ ) for most engineering purposes. 


\section{SOURCES OF DATA}

Two major compendia of recommended thermal-conductivity data for gases are available, ${ }^{7,8}$ but only one of these ${ }^{7}$ offers data for mixtures. As far as pure gases are concerned, both provide data well beyond $1200 \mathrm{~K}$.

In the case of pure helium, the TPRC data ${ }^{7}$ appear somewhat more reliable than those of Vargaftik. ${ }^{8}$ While below $1200 \mathrm{~K}$ the differences are small (between $-3 \%$ and $+3 \%$ with a crossover at $700 \mathrm{~K}$ ), at $2000 \mathrm{~K}$ Vargaftik's values are almost 15\% lower than the TPRC values. The latter are preferred because Vargaftik relies largely on his own measurements, which are then correlated and smoothed in some fashion: in the higher-temporaturc range, Llet TRRC values are based on experimental data from several investigators, ${ }^{9-11}$ which show a remarkable degree of agreement where they overlap. Finally, purely. analytical extrapolation of lower-temperature data, using the Kestin method, shows excellent agreement with the TPRC recommended values.

In the case of pure argon, the situation is similar; Vargaftik's values are about $2 \%$ higher than the TPRC values up to $1200 \mathrm{~K}$. The TPRC recommended values are based on both Russian ${ }^{12}$ and German ${ }^{13,14}$ experimental data at temperatures above $1000 \mathrm{~K}$ and on a large number of data at lower temperatures. Calculations using the Kestin procedure yield data in good agreement with TPRC recommendations. Vargaftik's recommended data appear to have been based on his own measurements up to about $1000 \mathrm{~K}$, and on a set of calculated data not considered by TPRC workers. The high-temperature (to 1500K) values in Vargaftik's 1970 standards publication appear to have been obtained by extrapolation.

As regards mixtures, $\operatorname{TPRC}^{7}$ presents both original experimental and smoothed data. Most are at room temperature, with the highest at $793 \mathrm{~K}$. In many cases the accuracy of these data is unlikely to match the authors' claims of $\pm 2 \%$, since even the pure-component data randomly differ from TPRC recommendations by as much as $\pm 2 \%$. 
One is thus drawn again to Kestin's conclusions that a well-founded calculation procedure may produce data at least equal in accuracy to extrapolations of available experimental data.

Both procedures will be offered in the following.

\section{PREDICTION METHODS}

\section{A. Simple Empirical Formulas}

1. Helium

Blais and Mann $^{9}$ suggest a simple linear equation for the thermal conductivity $\mathrm{k}$ :

$$
k=4.149+0.002839(\mathrm{~T}-1200)
$$

where $\mathrm{k}$ is in $\mathrm{mW} / \mathrm{cm} \mathrm{K}$ and $\mathrm{T}$ is in $\mathrm{K}$.

Petersen and Bonilla ${ }^{10}$ prefer.

$$
k=0.02273 \mathrm{~T}^{0.7352}
$$

A refinement of the Blais and Mann linear equation (1) gives

$$
k=0.45+0.003641 \mathrm{~T}-0.00458 \times 10^{-4} \mathrm{~T}^{2}
$$

Finally, Keyes $^{16}$ has proposed:

$$
k=\frac{0.1698 \sqrt{T}}{1+\frac{602}{T} \times 10^{-99.7 / T}}
$$

As shown in Table I, a11 of the above equations reproduce recommended TPRC values adequately in the range $500 \mathrm{~K}<\mathrm{T}<1300 \mathrm{~K}$. Equation (3) is recommended for simplicity and accuracy. 
Table I. Thermal Conductivity of Helium

\begin{tabular}{|c|c|c|c|c|c|c|}
\hline \multirow{3}{*}{$\mathrm{T}, \mathrm{K}$} & \multirow{3}{*}{$\begin{array}{l}\text { TPRC } \\
\text { recommended } \\
\text { value }^{a}\end{array}$} & \multicolumn{4}{|c|}{$\mathrm{k}, \mathrm{mW} / \mathrm{cm} \mathrm{K}$} & \multirow{3}{*}{$\begin{array}{c}\text { Calculated from Kestin's } \\
\text { theory of } \\
\text { corresponding states }\end{array}$} \\
\hline & & \multicolumn{4}{|c|}{ Calculated from Eq. } & \\
\hline & & (1) & (2) & (3) & (4) & \\
\hline 500 & 2.11 & 2.16 & 2.20 & 2.16 & 2.16 & 2.22 \\
\hline 600 & 2.47 & 2.45 & 2.51 & 2.46 & 2.47 & 2.52 \\
\hline 700 & 2.78 & 2.73 & 2.82 & 2.77 & 2.77 & 2.81 \\
\hline 800 & .3 .07 & 3.01 & 3.11 & 3.07 & 3.07 & 3.09 \\
\hline 900 & 3.35 & $3.3 n$ & 3.39 & 3.36 & 3.36 & 3.30 \\
\hline 1000 & 3.63 & 3.58 & 3.66 & 3.63 & 3.63 & 3.64 \\
\hline 1100 & 3.89 & 3.87 & 3.93 & 3.90 & 3.90 & 3.88 \\
\hline 1200 & 4.16 & 4.15 & 4.19 & 4.16 & 4.16 & 4.15 \\
\hline 1300 & 4.43 & 4.43 & 4.44 & 4.41 & 4.41 & 4.38 \\
\hline
\end{tabular}

$a_{\text {From Ref. }} 7$.

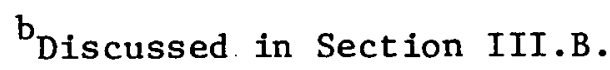

\section{Argon}

In the case of argon the choice of equations that adequately represent TPRC recommended data is more limited;

$$
k=.049+.00048 \mathrm{~T}-1 \times 10^{-7} \mathrm{~T}^{2}
$$

or

$$
\mathrm{k}=\frac{0.016 \sqrt{\mathrm{T}}}{1+\frac{182.5}{\mathrm{~T}} \times 10^{-1.57 / \mathrm{T}}}
$$


Equations. (5) and (6) are compared with TPRC data in Table II. Equation (6) Is recommended.

Table II. Therma1 Conductivity of Argon

\begin{tabular}{|c|c|c|c|c|}
\hline \multirow{3}{*}{$\mathrm{T}, \mathrm{K}$} & \multirow{3}{*}{$\begin{array}{l}\text { TPRC } \\
\text { recommended } \\
\text { value }^{a}\end{array}$} & \multicolumn{2}{|c|}{$\mathrm{k}, \mathrm{mW} / \mathrm{cm} \mathrm{K}$} & \multirow{3}{*}{$\begin{array}{c}\text { Calculated from Yestin's } \\
\text { theory of } \\
\text { corresponding states }\end{array}$} \\
\hline & & \multicolumn{2}{|c|}{$\begin{array}{l}\text { Calculated } \\
\text { from Eq. }\end{array}$} & \\
\hline & & (5) & (6) & \\
\hline 500 & 0.264 & 0.264 & 0.263 & 0.267 \\
\hline 600 & 0.301 & 0.301 & 0.301 & 0.305 \\
\hline 700 & 0.336 & 0.336 & 0.336 & 0.341 \\
\hline 800 & 0.369 & 0.369 & 0.369 & 0.374 \\
\hline 900 & 0.398 & 0.400 & 0.399 & 0.406 \\
\hline 1000 & 0.427 & 0.429 & 0.428 & 0.436 \\
\hline 1100 & 0.454 & 0.456 & 0.455 & 0.465 \\
\hline 1200 & 0.481 & 0.481 & 0.481 & 0.486 \\
\hline 1300 & 0.508 & 0.504 & 0.506 & 0.519 \\
\hline
\end{tabular}

$a_{\text {From Ref. } 7 .}$

\section{Mixtures}

The following empirical mixing rule is recommended:

$$
k_{\operatorname{mix}}(T)=\frac{k_{H e}(T)}{1+2.757 \frac{x_{A r}}{x_{H e}}}+\frac{k_{A r}(T)}{1+0.3322 \frac{x_{H e}}{x_{A r}}} \text {, }
$$

where $x$ denotes the molar fraction. The quasi-Wassiliewa coefficients (2..757 and 0.3322 ) have been determined by $a$ least-squares $f$ it to the available 
higher-temperature data.

Predicted values at $1000 \mathrm{~K}$ and $1200 \mathrm{~K}$, based on both Eq. 7 and the Kestin procedure, ${ }^{4-6}$ are given in Table III.

Table III. Thermal Conductivit.y ${ }^{a}$ of Helium-Argon Mixtures

\begin{tabular}{llllllll}
\hline \multicolumn{7}{c}{ Molar $\%$ He } & \\
\hline 0 & 20 & 40 & 50 & 60 & 80 & 100
\end{tabular}

$1000 \mathrm{~K}$

Eq. (7)

0.428

0.696

1.06

1.29

1.56

2.. 33

3.63

Kestin method

0.436

0.671

1.09

1.33

1.60

2.24

3.64

$1200 \mathrm{~K}$

Eq. (7)

0.481

0.789

1.20

1.47

1.74

2.67

4.16

Kestin method

0.486

0.750

1.12

1.36

1.66

2.54

4.15

${ }^{a}$ In $\mathrm{mW} / \mathrm{cm} \mathrm{K}$.

B. Kestin's Method, Based on the Theory of Corresponding States

For a full account of the theory the reader should see Refs. 2 and 4-6. Kest1n's method for the calculation of the thermal. conductivity of a dilute gas mixture requires the determination of the thermal conductivities associated with the separate pure gases, and of a mixture conductivity. The conductivities of the pure gases arise from collisions between like molecules and, according to the kinetic theory of gases, may be expressed as

$$
k=\frac{75}{64}\left(\frac{k_{B}^{3} N T}{\pi M}\right)^{1 / 2} \frac{F\left(T^{*}\right) f\left(T^{*}\right)}{\sigma^{2} \Omega^{2}, 2\left(T^{*}\right)}
$$


where

$$
\begin{aligned}
k_{B}= & 1.38044 \times 10^{-23} \mathrm{~J} / \text { molecule } \mathrm{K} \text { (Boltzmann's constant) } \\
\mathrm{N}= & 6.0268 \times 10^{26} \text { molecules/kmole (Avogadro's number) } \\
\mathrm{M}= & \text { molecular weight } \\
\sigma= & \text { scaling-length parameter (collision diameter) } \\
\mathrm{T}^{*}= & \text { reduced temperature }=\mathrm{T} /\left(\varepsilon / \mathrm{k}_{\mathrm{B}}\right) \\
\varepsilon= & \text { scaling-energy parameter (depth of intermolecular } \\
& \text { potential well) } \\
\mathrm{F}\left(\mathrm{T}^{*}\right)= & \text { universal therma1-conductivity correction } \\
\Omega^{2,2}\left(\mathrm{~T}^{*}\right) / \mathrm{f}\left(\mathrm{T}^{*}\right)= & \text { universal viscosity collision integral } \\
\Omega^{2,2}\left(\mathrm{~T}^{*}\right) / \mathrm{f}\left(\mathrm{T}^{*}\right)= & \exp \left\{0.45667-0.53955 \text { ln } \mathrm{T}^{*}+0.18265\left(\ell \mathrm{n} \mathrm{T}^{*}\right)^{2}\right. \\
& \left.-0.03629\left(\ell \mathrm{n} \mathrm{T}^{*}\right)^{3}+0.00241\left(\ell \mathrm{n} \mathrm{T}^{*}\right)^{4}\right\} \\
\mathrm{F}\left(\mathrm{T}^{*}\right)= & 1+0.0042\left\{1-\exp \left[0.33\left(1-\mathrm{T}^{*}\right)\right]\right\}
\end{aligned}
$$

For any pure monatomic gas, Eqs. (8)-(10), together with the two scaling parameters $\sigma$ and $\varepsilon$, are all that are necessary to determine the thermal conductivity at any temperature. The optimal scaling parameters have been determined by Kestin and his coworkers as follows: For helium, $\sigma=2.556 \AA$ and $\varepsilon / k_{B}=11.29$; for argon, $\sigma=3.291 \AA$ and $\varepsilon / k_{B}=153.61$. These data, together with the molecular weights of 4.003 and 39.948 , respectively, were used in calculating the last columns of Tables I and II.

Binary collisions between unlike molecules are accounted for by introducing a mixture conductivity and mixture scaling parameters. In contrast to the more usual "combination rules" for this conductivity, in Kestin's theory the mixture conductivity is given by an equation of the same form as (8) with universal collision functionals given by Eqs. (9) and (10. For the helium-argon system the appropriate scaling parameters are $\sigma_{12}=2.904 \AA$ and $\varepsilon_{12} / k_{B}=55.24$. For 
collisions involving species 1 and 2 ,

$$
k_{12}=\frac{75}{64}\left[\frac{k_{B}{ }^{3}\left(M_{1}+M_{2}\right) N T}{2 \pi M_{1} M_{2}}\right]^{1 / 2} \frac{F\left(T_{12}{ }^{*}\right)}{\Omega^{2,2}\left(T_{12}{ }^{*}\right) \cdot \sigma_{12}{ }^{2}}
$$

where $\mathrm{T}_{12}^{*}=\mathrm{T} /\left(\varepsilon_{12} / \mathrm{k}_{\mathrm{B}}\right)$. It should be noted that this conductivity is independent of the molar composition of the mixture.

Finally, the thermal conductivity of a binary mixture of specified composition is (Refs. 1 and 2)

$$
k_{\operatorname{mix}}=\frac{1+Z}{X+Y}
$$

where

$$
\begin{aligned}
& \mathrm{x}=\frac{\mathrm{x}_{1}^{2}}{\mathrm{k}_{1}}+\frac{2 \mathrm{x}_{1} \mathrm{x}_{2}}{\mathrm{k}_{12}}+\frac{\mathrm{x}_{2}{ }^{2}}{\mathrm{k}_{2}} \\
& \mathrm{Y}=\frac{\mathrm{x}_{1}{ }^{2}}{\mathrm{k}_{1}} \mathrm{U}_{1}+\frac{2 \mathrm{x}_{1} \mathrm{x}_{2}}{\mathrm{k}_{1}} \mathrm{U}_{\mathrm{y}}+\frac{\mathrm{x}_{2}{ }^{2}}{\mathrm{k}_{2}} \mathrm{U}_{2} \\
& \mathrm{z}=\mathrm{x}_{1}{ }^{2} \mathrm{u}_{\mathrm{i}}+2 \mathrm{x}_{1} \mathrm{x}_{2} \mathrm{u}_{\mathrm{z}}+\mathrm{x}_{2}{ }^{2} \mathrm{u}_{2} \\
& \mathrm{II}_{1}=\frac{4}{15} \mathrm{~A}_{12} *-\frac{1}{12}\left(\frac{12}{5} \mathrm{~B}_{12} *+1\right) \frac{\mathrm{M}_{1}}{\mathrm{M}_{2}}+\frac{1}{2} \frac{\left(\mathrm{M}_{1}-\mathrm{M}_{2}\right)^{2}}{\mathrm{M}_{1} \mathrm{M}_{2}} \\
& U_{2}=\frac{4}{15} \cdot A_{12} *-\frac{1}{12}\left(\frac{12}{5} B_{12} *+1\right) \frac{M_{2}}{M_{1}}+\frac{1}{2} \frac{\left(M_{1}-M_{2}\right)^{2}}{M_{1} M_{2}} \\
& U_{y}=\frac{4}{15} A_{12} * \frac{\left(M_{1}+M_{2}\right)^{2}}{4 M_{1} M_{2}} \frac{k_{12}}{k_{1} k_{2}}-\frac{1}{12}\left(\frac{12}{5} B_{12} *+1\right) \\
& -\frac{5}{32 A_{12}}\left(\frac{12}{5} B_{12} *-5\right) \frac{\left(M_{1}-M_{2}\right)^{2}}{M_{1} M_{2}}
\end{aligned}
$$




$$
\begin{aligned}
U_{z}= & \frac{4}{15} A_{12} *\left\{\left[\frac{\left(M_{1}+M_{2}\right)^{2}}{4 M_{1} M_{2}}\right]\left(\frac{k_{12}}{k_{1}}+\frac{k_{12}}{k_{2}}\right)-1\right\} \\
& -\frac{1}{12}\left(\frac{12}{5} B_{12} *+1\right) ;
\end{aligned}
$$

$x_{1}$ and $x_{2}$ are the mole fractions of each component and $A_{12}^{*}$ and $B_{12}^{*}$ are additional universal functionals of the reduced temperature, given by

$$
\begin{aligned}
A^{*}= & \exp \left[0.10967-0.09555 \ln T^{*}+0.08965\left(\ln T^{*}\right)^{2}\right. \\
& \left.-0.02629\left(\ln T^{*}\right)^{3}+0.00241\left(\ln T^{*}\right)^{4}\right]
\end{aligned}
$$

and

$$
\begin{aligned}
& \mathrm{B}^{*}=\exp \left[0.15529-0.042985 \ell \mathrm{nT} *-0.000213\left(\ln \mathrm{T}^{*}\right)^{2}\right. \\
& \left.+0.003068\left(\ln T^{*}\right)^{3}-0.000229\left(\ln T^{*}\right)^{4}\right]
\end{aligned}
$$

The calculation procedure has been checked agalnst the TPRC smoothed data for helium-argon mixtures at 343.2 and $793.2 \mathrm{~K}$. The agreement is within $2 \%$ and $4 \%$, respectively. The corresponding-states procedure is not difficult to perform, even with a hand calculator. Thus, for temperatures less than about $800 \mathrm{~K}$, Kestin's method is recommended. For higher temperatures, however, the error due to Kestin's method may increase beyond $4 \%$ and therefore an empirical correlation is suggested as described below.

Since the mixture data extrapolated to pure components show progressively worse agreement with other pure-component measurements at higher temperatures, the increasing discrepancy between the mixture data and the Kestin prediction may well be due to expcrimental errors rather than faulty theory. Until this matter is resolved 
by more precise measurements, it is recommended that for mixtures with small concentrations of either component the Kestin prediction method be used, while for other mixtures the modified procedure outlined in section $C$ be employed.

\section{Numerical Data Fitting}

For helium-argon gas mixtures in which the argon mole fraction ( $\mathrm{x}$ ) varies from 0.2 to 0.8 , the following expression is recommended:

$$
\mathrm{k}_{\mathrm{ul}}=\left(\mathrm{k}_{\mathrm{k}}+\mathrm{k}_{\mathrm{E}}\right) / 2
$$

where $k_{m}=$ conductivity of the mixture,

$$
\begin{aligned}
& k_{K}= \text { conductivity calculated by Kestin's method as } \\
& \text { recommended ahnve, }
\end{aligned}
$$

and

$$
\mathrm{k}_{\mathrm{E}}=\mathrm{A}_{0}+\mathrm{A}_{1} \mathrm{~T}+\mathrm{A}_{2} \mathrm{X}+\mathrm{A}_{3} \mathrm{X}^{2}+\mathrm{A}_{4} \mathrm{O}_{1}+\mathrm{A}_{6} \mathrm{Q}_{1} 1 \mathrm{nT}+\mathrm{A}_{7} \mathrm{Q}_{1} \mathrm{~T}^{-2}+\mathrm{A}_{8} \mathrm{Q}_{2} \mathrm{~T}^{-2}
$$

where

$$
\begin{aligned}
& A_{0}=0.75 \\
& A_{1}=2.64 \times 10^{-3} \\
& A_{2}=-3.92 \\
& A_{3}=1.50 \\
& A_{4}=12.16 \\
& A_{5}=0.866 \\
& A_{6}=-4.45 \\
& A_{7}=6.67 \times 10^{3} \\
& A_{8}=-1.369 \times 10^{5} \\
& X=\text { mole fraction argon. } \\
& Q_{n}=\left[1 . \text { exp }\left(-2 x^{n+1}\right)\right] . \\
& T=\text { temp. in degrees Kelvin. }
\end{aligned}
$$


The expression shown in Eq. (23) was arrived at by a trial-and-error procedure which attempted to minimize the mean square error between Eq. (23) and the raw data given in Ref. 7.

The overall accuracy of the expression given in Eq. (22) is estimated to be better than $\pm 4 \%$ in the temperature range of $800-1200 \mathrm{~K}$. The accuracy of $k_{\vec{E}}(E q: 23)$ alone is estimated to be $+5 \%$. The raw TPRC data ${ }^{7}$ available up to about $793 \mathrm{~K}$ for helium-argon mixtures, as well as the calculated values of $\mathrm{k}_{\mathrm{E}}$ based on Eq. (23), are shown in Fig. 1 .

An accuracy of $\pm 5 \%$ can be achieved by using either the method recommended by Kestin [Eq. (12)] or Eq. (23) (or Fig. 1). However, it appears that for the high-temperature regime $(T>800 \mathrm{~K})$. Eq. (23) overpredicts the thermal conductivity value, whlle Eq. (12) underpredicts it. Therefore, Eq. (22), which gives an average of the two values, is recommended when greater accuracy is desired.

It should again be noted that the above recommendation is based on empirical analysis and on the theoretical model of Kestin, and is therefore only a "best estimate." Actual experimental data are required to verify the accuracy of the recommended procedure. 


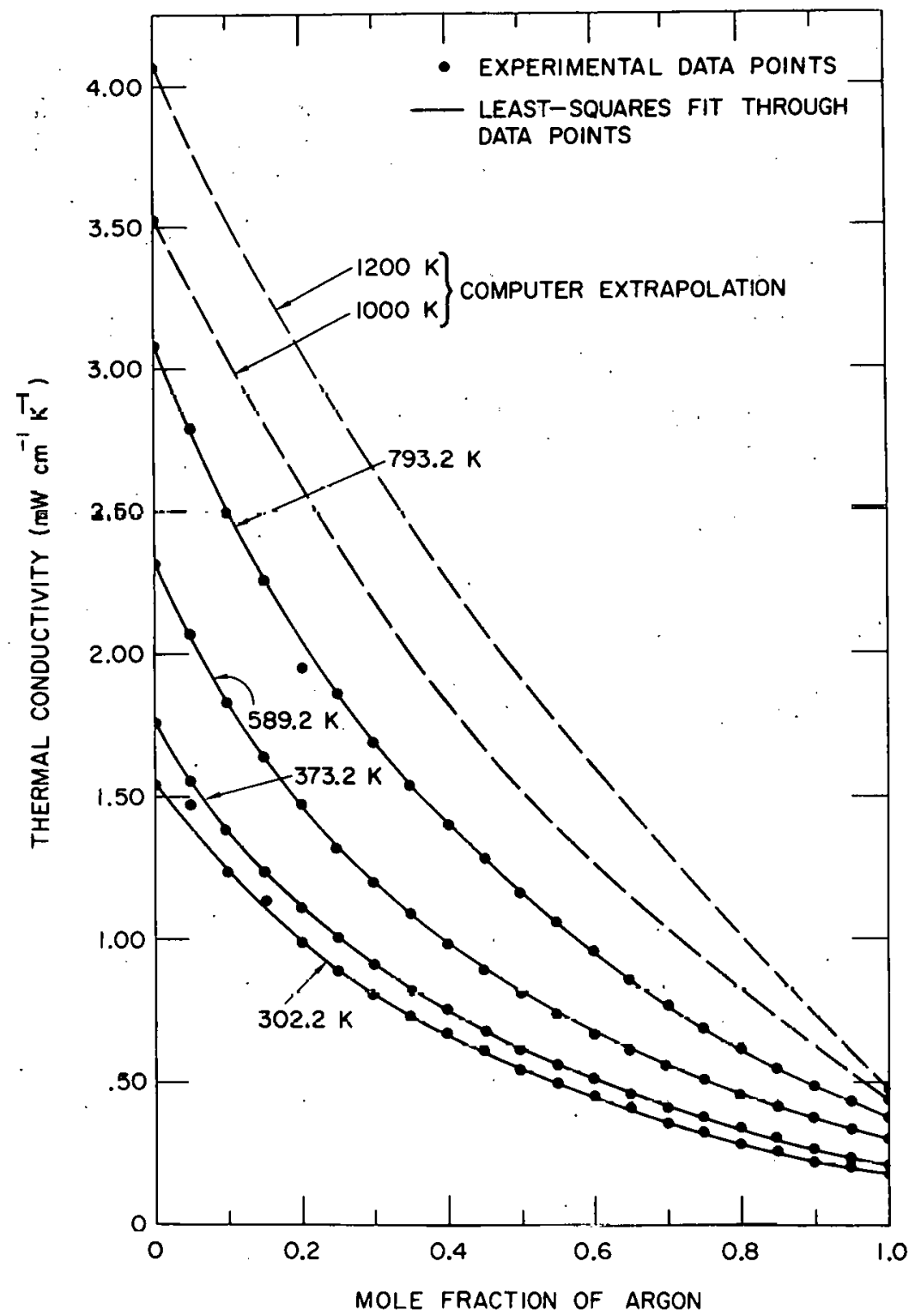

Fig. 1. Thermal Conductivity of Helium-Argon Systems at. Selected Temperatures. Neg. No. MSD-64184. 


\section{REFERENCES}

1. S. Chapman and T. G. Cowling, The Mathematical Theory of Non-Uniform Gases, Cambridge University Press, London (1952).

2. J. O. Hirschfelder, C. F. Curtiss, and R. B. Bird, Molecular Theory og Gases and Liquids, John Wiley, New York (1964).

3. J. H. Ferziger and H. G. Kaper, Mathematical Theory of Transport Processes In Gases, Norlh Hulland, Ainsterdam (1972).

4. J. Kestin, S. T. Ro, and W. A. Wakeham, Physics 58, 165 (1972).

5. J. Kestin and E. A. Mason, Transport Properties in Gases; Comparisons Between Theory and Experiment, AIP Conf. Proc. No. 11, J. Kestin, Ed., p. 137 (1973).

6. J. Kestin, Transport Properties of Mixtures, Survey Lecture presented at 7.th Symp. on Thermophysical Properties, ASME-NBS, May 1977; to be published.

7. Y. Touloukian, P. J. Liley, and S. C. Saxena, Thermal Conductivity of Gases, TPRC Data Series Vol. 3, Plenum Press, New York (1970).

8. N. B. Vargaftik, Handbook of Thermophysical Properties of Gases and Liquids (in Russian), Nauka, Moscow (1972).

9. N. C. Blais and J. B. Mann, Thermal Conductivity of Helium and Hydrogen at High Temperatures, J. Chem. Phys. 32, 1459 (1960).

10. J. R. Petersen and C. F. Bonilla, Advances in Thermophysical Properties at Extreme Temperatures and Pressures, 3rd Symp. on Thermophysical Properties, ed. S. Gratch, ASME, p. 264 (1965).

11. E. G. D. Cohen, M. J. Offerhaus, and J. deBoer, Physica 20, 501 (1954).

12. N. B. Vargaftik and N. H. Zimina, High Temp. Phys. 2, 645 (1964).

13. K. Schafer and F. W. Reiter, Naturwissenschaften 43, 296 (1956).

14. K. Schafer and F. W. Reiter, Elektrochem. 61, 1230 (1957).

15. N. B. Vargaftik and L. P. Filippov, Thermal Conductivity of Gases and Liquids (In Russian), Standards Publications, Moscow (1970).

16. F. G. Keyes, Trans. ASME 76, 809 (1954). 
Distribution for $\mathrm{ANL}-79-3$

Interna1:

$\begin{array}{lll}\text { J. A. Kyger } & \text { E. Stefanski (4) } & \text { K. J. Reimann } \\ \text { R. Avery } & \text { T. H. Blewitt } & \text { R. W. Siegel } \\ \text { L. Burris } & \text { M. B. Brodsky } & \text { D. Stahl } \\ \text { D. W. Cissel } & \text { W. J. Shack } & \text { H. R. Thresh } \\ \text { S. A. Davis } & \text { F. Y. Fradin } & \text { H. Wiedersich } \\ \text { B. R. T. Frost } & \text { A. G. Hins } & \text { S. A. Miller } \\ \text { R. J. Teunis } & \text { T. F. Kassner } & \text { W. N. Beck } \\ \text { C. E. Till } & \text { A. P. L. Turner } & \text { E. E. Feldman } \\ \text { R. S. Zeno } & \text { S. Majumdar } & \text { O. S. Seim } \\ \text { H. K. Fauske } & \text { P. S. Maiya } & \text { D. T. Raske } \\ \text { H. O. Monson } & \text { K. L. Merkle } & \text { A. B. Krisciunas } \\ \text { R. W. Weeks } & \text { M. H. Mueller } & \text { ANL Contract File } \\ \text { L. I'. Lloyd } & \text { R. B. Pocppel } & \text { ANL LIbrarles (5) } \\ \text { J. F. Schumar } & \text { A. Purohit (10) } & \text { TIS Files (6) }\end{array}$

External:

DOE-TIC, for distribution per UC-77 (176)

Manager, Chicago Operations Office

Chief, Utfice of Patent C'ounsel, CH

Director, Reactor Programs Div., $\mathrm{CH}$

Director, CH-INEL

Chief, GCFR Branch, RRT-DOE (2)

President, Argonne Universities Association

Materials Science Division Review Committee:

E. A. Aitken, General Electric Co., Sunnyvale

G. S. Ansell, Rensselaer Polytechnic Institute

R. W. Balluffi, Massachusetts Inst. Technology'

R. J. Birgeneau, Massachusetts Inst. Technology

S. L. Cooper, U. Wisconsin

C. Laird, U. Pennsylvania

M. T. Simnad, General Atomic

C. T. Tomizuka, U. Arizona

A. R. C. Westwood, Martin Marietta Labs. 